\title{
Changes in soil organic carbon during 22 years of pastures, cropping or integrated crop/livestock systems in the Brazilian Cerrado
}

\author{
Selenobaldo A. C. de Sant-Anna • Claudia P. Jantalia • Jerusa M. Sá • Lourival Vilela • \\ Robélio L. Marchão • Bruno J. R. Alves · Segundo Urquiaga • Robert M. Boddey (1)
}

Received: 25 May 2016/Accepted: 18 November 2016

(C) Springer Science+Business Media Dordrecht 2016

\begin{abstract}
In Brazil's central savanna region, government policy is to encourage the conversion of conventional plough tillage (PT) agriculture to no-till (NT) and raise the productivity of under-utilized pastures, including their conversion to integrated croplivestock (ICL) systems, with the objective of increasing soil organic carbon (SOC) at the expense of atmospheric carbon dioxide. An experiment was established in 1991 by liming and fertilizing at two levels an area of native vegetation (NV). The treatments, replicated in randomized plots, included pastures, continuous cropping and ICL systems under PT or NT. The aim of this study was to quantify the SOC accumulation to $100 \mathrm{~cm}$ depth under these treatments over time. The high $\mathrm{C}: \mathrm{N}$ ratios suggested
\end{abstract}

Electronic supplementary material The online version of this article (doi:10.1007/s10705-016-9812-z) contains supplementary material, which is available to authorized users.

S. A. C. de Sant-Anna · J. M. Sá

Department of Soil Science, Universidade Federal Rural do Rio de Janeiro, BR 465, Km 07, Seropédica,

RJ 23890-000, Brazil

C. P. Jantalia - B. J. R. Alves · S. Urquiaga

R. M. Boddey $(\square)$

Embrapa Agrobiologia, Rodovia BR 465, Km 07,

Seropédica, Rio de Janeiro 23891-000, Brazil

e-mail: robert.boddey@embrapa.br

L. Vilela $\cdot$ R. L. Marchão

Embrapa Cerrados, CP 08223, Planaltina, DF 73301-970, Brazil that there was a high proportion of charcoal present in the soil. Increasing fertilizer inputs had no overall significant effect on SOC stocks. Stocks of SOC changed little under pastures. Analyses of ${ }^{13} \mathrm{C}$ abundance showed that higher fertilizer inputs increased the decomposition rate of $\mathrm{C}$ derived from $\mathrm{NV}$ under pure grass pastures. Continuous cropping under NT preserved SOC and under PT there were significant losses. The highest SOC stocks were found under ILP treatments, but not all ILP treatments accumulated SOC even under NT. These results indicate that government initiatives to substitute PT with NT and to intensify beef cattle production will have only modest short-term gains in SOC accumulation.

Keywords ${ }^{13} \mathrm{C}$ abundance $\cdot$ Carbon sequestration . Cerrado region $\cdot$ Charcoal $\cdot$ Forage legume $\cdot$ Integrated crop livestock systems $\cdot$ Soil carbon $\cdot$ Tropical pastures

\section{Introduction}

The Brazilian government pledged at COP 15 in Copenhagen in 2010 as nationally appropriate mitigation actions (NAMAs), the adoption of integrated crop-livestock (ICL) systems (range of estimated reduction of greenhouse gases [GHG] equivalent to 18-22 Tg [millions of tonnes] of $\mathrm{CO}_{2}\left[\mathrm{CO}_{2} \mathrm{eq}\right]$ until 2020) and recovery of degraded pastures (range of estimated reduction: 83-104 $\mathrm{Tg}$ of $\mathrm{CO}_{2}$ eq until 2020). 
Subsequently at COP21 in Paris in 2015, the Brazilian government presented their Intended Nationally Determined Contributions (iNDCs) for the agriculture sector to strengthen the Low Carbon Agriculture $(\mathrm{ABC})$ program as the main strategy for sustainable agriculture development. These iNDCs include the recovery of 15 million ha (Mha) of degraded pasturelands and the installation of 5 Mha of integrated croplivestock-forestry systems (ICLF) by 2030. Expansion of cropping areas under no-tillage is also among the proposed NAMAs but not as an iNDC.

One of the pillars of the proposed reductions is the removal of $\mathrm{CO}_{2}$ from the atmosphere by increasing stocks of soil carbon promoted by the recovery of degraded pastures or the introduction of integrated crop/livestock systems. Most studies conducted in several of Brazil's important cattle-producing regions strongly indicate that soil $\mathrm{C}$ is higher under productive pastures than under degraded pastures (e.g. Neill et al. 1997; Nepstad et al. 1994; Braz et al. 2013). In addition, the soil-fertility status influences pasture productivity and consequently the accumulation of $\mathrm{C}$ in soil (Carvalho et al. 2010). For soils of the Central savannah of Brazil (Cerrado region) it was demonstrated that $\mathrm{N}$ is the most limiting nutrient for pasture growth but the supply of $\mathrm{P}, \mathrm{K}$ and $\mathrm{S}$ also brought about increased pasture biomass production (Oliveira et al. 2001). The use of forage legumes to supply biologically fixed $\mathrm{N}_{2}$ to the pasture is a possibility to avoid economic constraints with $\mathrm{N}$ fertilization and has the potential to stock more $\mathrm{C}$ in soil than low yielding pastures (Tarré et al. 2001; Mortenson et al. 2004). However, the use of mixed grass/legume pastures in Brazil is not common and persistence of the legume in such swards is generally the principal problem to maintain the $\mathrm{N}$ input from the legume (Boddey et al. 2015).

ICL systems were proposed to recover pastures with the surplus nutrients derived from a preceding crop treated with fertilizers, the cost of which are abated by commercializing the grain produced. Results on the impact on soil C stocks of the conversion of degraded pastures to ICL systems are rare. Salton et al. (2014) examined the soil layer of $0-20 \mathrm{~cm}$ of a long-term experiment and verified that soil C stocks reached the highest levels in a pure wellmanaged pasture followed by soybean based ICL systems with crops managed under no-tillage. They also showed that the use of continuous cropping under plough tillage (PT) resulted in the lowest soil C stocks. Apart from adjusting $\mathrm{C}$ and $\mathrm{N}$ inputs, the use of notillage has the potential to enhance soil $\mathrm{C}$ stocks in cropping systems (Boddey et al. 2010), and this was also defended by Carvalho et al. (2010) when comparing ICL systems.

The studies on soil $\mathrm{C}$ stocks have been based on the comparison of neighbouring areas of productive and degraded pastures and often also the stocks of soil $\mathrm{C}$ under remaining native vegetation-the chronosequence approach. Using this approach in the Cerrado region, higher soil $\mathrm{C}$ stocks were reported under ungrazed or lightly grazed pastures than under the native vegetation (Corazza et al. 1999; Chapuis-Lardy et al. 2002; da Silva et al. 2004). More recently, Braz et al. (2013) published a chronosequence study performed in the Cerrado region comparing areas of native vegetation with adjacent productive and degraded pastures. They concluded that pastures that were indicated to be more productive by, inter-alia, their regrowth rate and rates of litter deposition, showed higher soil $\mathrm{C}$ stocks than those under the natural vegetation and also above those under degraded pastures. These differences were greater in soils of higher clay content.

The chronosequence approach requires that the land use under comparison are located in areas presenting the same soil type and management history. As this is not easy to prove, the use of long-term experiments where soil samples were taken at the time of establishment and analysed and stored are regarded the "gold standard" to assess changes in soil C (and N) stocks over time (Smith et al. 2012). Such studies do not appear to have been performed in Brazil, but medium term (10-20 years) experiments with treatments comparing different crop rotations under either PT and NT arranged in randomised block designs have shown that NT does preserve soil C compared to PT (e.g. Bayer et al. 2000, 2002; Sisti et al. 2004; Diekow et al. 2005; Boddey et al. 2010). A similar conclusion was arrived at by Zotarelli et al. (2012), however, when the final soil $\mathrm{C}$ stocks of each crop rotation were compared with the stocks 12 years earlier in the same plot the conclusion was that the higher soil C stocks under NT were due to lower losses than those observed under PT and not gains under NT.

The objective of this study was to investigate the impact of different land-use systems: continuous pastures, continuous cropping or integrated crop/ 
livestock systems under two levels of soil fertility status on changes of soil $\mathrm{C}$ and $\mathrm{N}$ stocks 22 years after conversion of the land use from native Cerrado vegetation.

\section{Materials and methods}

The experiment was situated at the field station of the Embrapa Cerrados Centre $\left(15^{\circ} 39^{\prime} \mathrm{S}, 47^{\circ} 44^{\prime} \mathrm{W}\right)$ near Planaltina (Federal District) which prior to installation was native Cerrado vegetation of the type Cerrado "sensu stricto" (Eiten 1972) consisting of shrubs and small trees in a continuous carpet of grasses. The soil in this area is classified by the US Soil Taxonomy system as an Oxisol (Typic Acrustox) or "Latossolo Vermelho" by the Brazilian classification. A fuller description of the soil at this site was given by Chapuis-Lardy et al. (2002) and the analysis of the soil under the native vegetation (NV) is given in Table 1.

In 1991 the area was cleared of NV and lime was added to the whole experimental area. The experiment consisted of eight basic land-use treatments at two fertilizer/lime levels (F1 and F2) arranged in a randomized complete block factorial design ( 8 land uses $\times 2$ fertilizer levels). Two areas at each end of experiment remained as undisturbed native vegetation with no lime addition, giving four replicate areas of NV. For the lower fertility (F1) lime was added at 3.4 $\mathrm{Mg} \mathrm{ha}^{-1}$ and for F2 at $5.8 \mathrm{Mg} \mathrm{ha}^{-1}$. The land-use treatments were pastures, either pure grass or mixed with a forage legume, continuous cropping under notill or plough tillage (PT-disc plough followed by a harrow), or integrated crop/livestock (ICL) system. There were eight land use treatments at each of the two fertility levels, which resulted in a factorial design $8 \times 2$, with four replicates. Land use treatments were as follows:

(a) Continuous pasture (grass monoculture)

(b) Continuous grass/legume mixed pasture

(c) Continuous cropping under NT

(d) Continuous cropping under PT

(e) ILC -4 years pasture followed by 4 years cropping with all crops and pastures implanted with NT.

(f) ILC -4 years pasture followed by 4 years cropping with all crops and pastures implanted with PT. (g) ILC - 4 years cropping followed by 4 years pasture with all crops and pastures implanted with NT.

(h) ILC -4 years cropping followed by 4 years pasture with all crops and pastures implanted with PT.

The sequence of crops/pasture species in the eight land-use systems over the 22-year period is given in Table 2. The total of all applications of fertilizers to each treatment is given in the Table 3 . Each treatment had four replicate plots of $40 \times 50 \mathrm{~m}(\mathrm{~N}=4)$. In the continuous cropping treatments under NT and PT, just one crop per year was planted at the start of the rainy season (November). After harvest it was left fallow until the next year. In the PT treatment the residues of the crop after harvest were buried with a disc plough. Over the 22 years of cropping there were 14, 5, 2, and 1 years respectively, of soybean, maize, millet and sorghum (Table 2) always followed by fallow from the end of one rainy season until the start of the next.

In the ICL and the continuous pasture treatments, all pastures were grazed by Nellore cattle (Bos indicus), the total animal weight being regulated by introducing or removing animals such that the green forage on offer was between approximately $8-10 \mathrm{~kg}$ per $100 \mathrm{~kg}$ of animal live weight.

\section{Soil sampling}

Three sets of soil samples were taken from the pasture, ICL and continuously cropped plots in and four areas of the neighbouring native vegetation (NV) in 2013. In 2001 one set of four undeformed samples were taken from each plot to assess soil bulk density by using a bevelled ring of known volume $\left(84.9 \mathrm{~cm}^{3}\right)$ driven into each of the four the sides of sampling trenches dug to over $100 \mathrm{~cm}$ depth in 2001, as described by Sisti et al. (2004). The depth intervals were $0-5,5-10,10-20$, $20-30,30-40,40-60,60-80$ and $80-100 \mathrm{~cm}$. The samples were dried at $110{ }^{\circ} \mathrm{C}$ for the assessment of dry weight and subsequently soil bulk density.

In the years 2001, 2009 and 2013 samples were taken for analysis of total $\mathrm{C}$ and $\mathrm{N}$ content using a Dutch auger from the same depth intervals as for the evaluation of soil density at five points in each plot and in the four areas of NV and bulked to constitute one sample per depth interval per plot. In 2001 all plots of pasture treatments were sampled, but only plots of the 
Table 1 Fertility analyses for the soil under the Cerrado native vegetation, the pastures and the continuous cropping taken in 2013

\begin{tabular}{|c|c|c|c|c|c|c|c|c|}
\hline System & Depth & $\begin{array}{l}\mathrm{pH} \\
\left(\mathrm{H}_{2} \mathrm{O}\right)\end{array}$ & $\begin{array}{l}\mathrm{Al} \\
\mathrm{cmo}\end{array}$ & ${ }_{3} \mathrm{Ca}$ & $\mathrm{Mg}$ & $\mathrm{H}+\mathrm{Al}$ & $\begin{array}{l}\mathrm{K} \\
\mathrm{mg} / \mathrm{L}\end{array}$ & $\mathrm{P}$ \\
\hline \multirow[t]{2}{*}{ Cerrado native vegetation } & $0-10$ & 4.8 & 0.7 & 0.5 & 0.3 & 9.1 & 58 & 1.7 \\
\hline & $10-20$ & 4.9 & 0.5 & 0.0 & 0.1 & 7.2 & 31 & 1.2 \\
\hline \multirow[t]{2}{*}{ Pure grass pasture F1 } & $0-10$ & 5.5 & 0.1 & 1.7 & 0.7 & 6.6 & 99 & 1.8 \\
\hline & $10-20$ & 5.5 & 0.1 & 1.1 & 0.5 & 6.4 & 40 & 1.1 \\
\hline \multirow[t]{2}{*}{ Pure grass pasture only F2 } & $0-10$ & 5.7 & 0.0 & 2.1 & 1.0 & 5.6 & 68 & 3.6 \\
\hline & $10-20$ & 5.6 & 0.0 & 1.6 & 0.7 & 4.8 & 21 & 0.8 \\
\hline \multirow[t]{2}{*}{ Mixed grass/legume pasture F1 } & $0-10$ & 5.3 & 0.2 & 1.4 & 0.5 & 6.5 & 58 & 2.1 \\
\hline & $10-20$ & 5.3 & 0.1 & 1.1 & 0.4 & 5.9 & 26 & 1.5 \\
\hline \multirow[t]{2}{*}{ Mixed grass/legume pasture F2 } & $0-10$ & 5.6 & 0.1 & 2.1 & 1.0 & 5.6 & 95 & 1.4 \\
\hline & $10-20$ & 5.5 & 0.1 & 1.6 & 0.7 & 5.6 & 51 & 0.9 \\
\hline \multirow[t]{2}{*}{ Continuous cropping CT F1 } & $0-10$ & 4.7 & 0.5 & 0.7 & 0.1 & 8.3 & 80 & 4.1 \\
\hline & $10-20$ & 4.7 & 0.4 & 0.5 & 0.1 & 7.9 & 22 & 1.7 \\
\hline \multirow[t]{2}{*}{ Continuous cropping CT F2 } & $0-10$ & 5.1 & 0.2 & 1.8 & 0.3 & 7.0 & 110 & 8.3 \\
\hline & $10-20$ & 5.1 & 0.2 & 1.3 & 0.3 & 6.3 & 42 & 2.4 \\
\hline \multirow[t]{2}{*}{ Continuous cropping NT F1 } & $0-10$ & 5.2 & 0.2 & 1.7 & 0.5 & 7.2 & 57 & 4.5 \\
\hline & $10-20$ & 4.5 & 0.5 & 0.2 & 0.1 & 7.5 & 19 & 2.7 \\
\hline \multirow[t]{2}{*}{ Continuous cropping NT F2 } & $0-10$ & 5.8 & 0.0 & 3.0 & 0.6 & 5.4 & 87 & 11.7 \\
\hline & $10-20$ & 4.8 & 0.3 & 0.7 & 0.2 & 7.4 & 27 & 3.1 \\
\hline
\end{tabular}

Determinations made according to Embrapa (1997) Manual of soil analysis. Al and $\mathrm{H}+\mathrm{Al}$ Titration, Ca and Mg by Atomic adsorption spectroscopy, K by flame photometry and P (Mehlich I) by colorimetry

higher fertility level (F2) were sampled for the ICL and continuous cropping. In 2009, plots of all F2 treatments were sampled. In 2013, all plots of both F1 and F2 and the NV were sampled at 5 points with an auger to all depth intervals to $100 \mathrm{~cm}$. The bulked samples for each depth interval for each plot were air dried and then passed through a $2 \mathrm{~mm}$ sieve. Aliquots of the samples from the $0-30 \mathrm{~cm}$ depth intervals were taken for soil fertility analyses, and other aliquots were finely ground $(<100$ mesh) using a roller grinder similar to that described by Arnold and Schepers (2004).

\section{Soil analyses}

All bulked soil samples taken with the auger to $30 \mathrm{~cm}$ depth were analysed for $\mathrm{pH}$, exchangeable $\mathrm{Ca}, \mathrm{Mg}, \mathrm{Al}$ and $\mathrm{K}$ and for available $\mathrm{P}$ (Mehlich I) using standard techniques (Embrapa 1997). Results of fertility analyses for the soil to depth of $20 \mathrm{~cm}$ under the NV, the pastures and the continuous cropping treatments are displayed in Table 1. Analyses of the fertility parameters under all treatments to $30 \mathrm{~cm}$ are in the supplementary information Table SI 01.

The concentrations of total $\mathrm{N}$ and $\mathrm{C}$ and the ${ }^{13} \mathrm{C}$ isotopic abundance of the finely-ground soil samples taken in 2013 were determined on sub-samples containing between 200 and $400 \mu \mathrm{g}$ total $\mathrm{C}$ using a continuous-flow isotope-ratio mass spectrometer (Finnigan DeltaPlus or Delta V mass spectrometer coupled to the output of a Costech (model ECS4010) total C and $\mathrm{N}$ analyser-Finnigan MAT, Bremen, Germany) in the "John Day Stable Isotope Laboratory" at Embrapa Agrobiologia (RJ). For the samples taken in 2001, the total $\mathrm{C}$ and $\mathrm{N}$ analyser used a Carlo Erba EA 1108, and for the samples taken in 2009 and 2013 using the Costech $\mathrm{CN}$ analyser. All samples taken to a depth of $30 \mathrm{~cm}$ in 2001 and 2009 were reanalysed simultaneously (randomised in the same carousels) with the 2013 samples using the Costech $\mathrm{CN}$ analyser. The $\mathrm{N}$ concentration in the samples was estimated for the 2001 and 2009 samples using the semi-micro Kjeldahl technique as described by Urquiaga et al. (1992). 


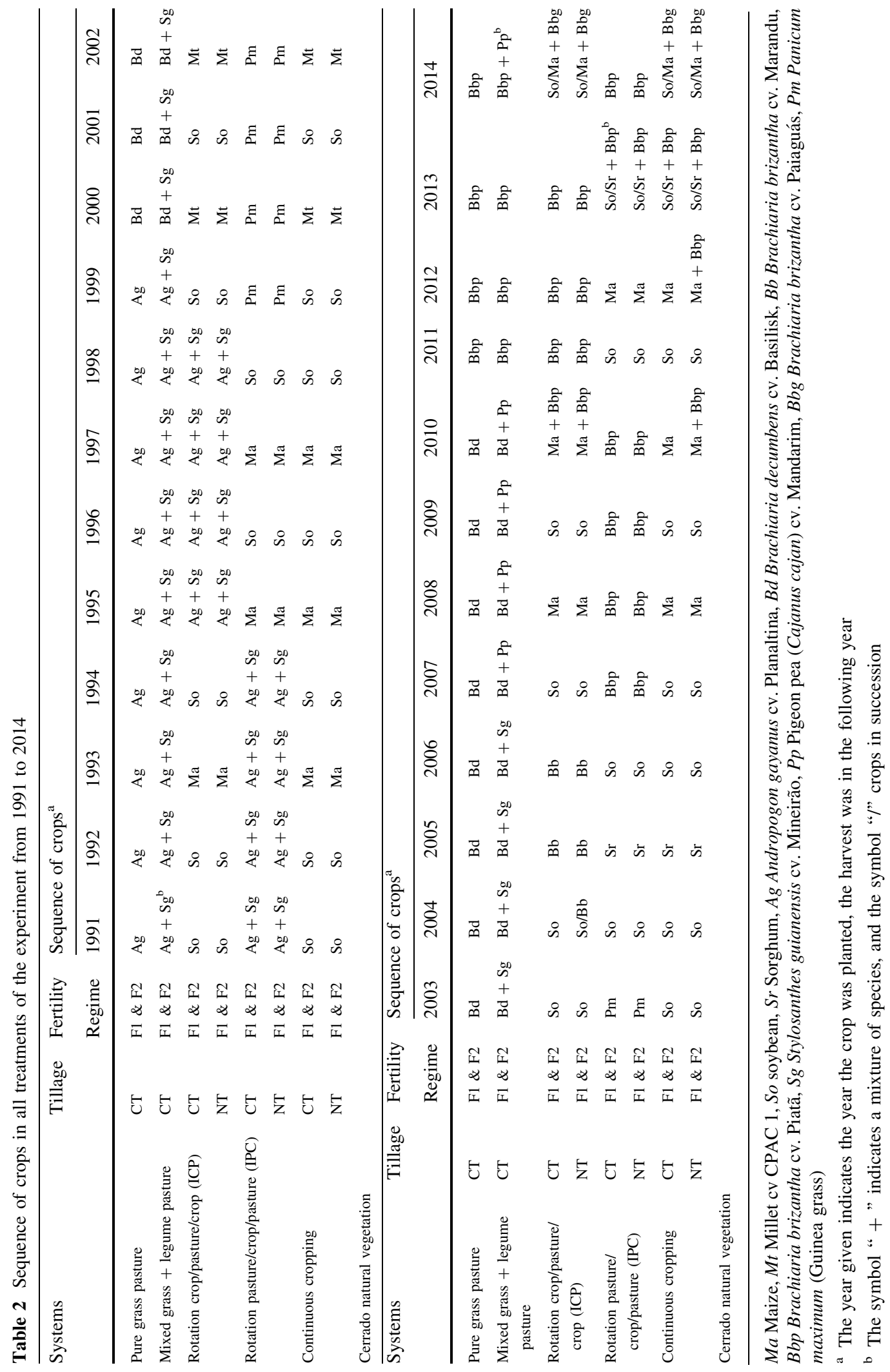


Table 3 Total additions of lime and fertilizers from the start of the experiment (1991) until 2013

\begin{tabular}{|c|c|c|c|c|c|c|}
\hline System & $\begin{array}{l}\text { Lime } \\
\left(\mathrm{Mg} \mathrm{ha}^{-1}\right)\end{array}$ & Gypsum & $\begin{array}{l}\mathrm{N}^{\mathrm{a}} \\
\left(\mathrm{kg} \mathrm{ha}^{-1}\right)\end{array}$ & $\mathrm{P}^{\mathrm{a}}$ & $\mathrm{K}^{\mathrm{a}}$ & Micro $^{\mathrm{b}}$ \\
\hline \multicolumn{7}{|c|}{ Continous cropping } \\
\hline $\mathrm{F} 1$ & 7.1 & 1.5 & 263 & 434 & 638 & 43 \\
\hline $\mathrm{F} 2$ & 10.6 & 4.3 & 443 & 842 & 1379 & 85 \\
\hline \multicolumn{7}{|c|}{ ICP (cropping start) } \\
\hline $\mathrm{F} 1$ & 7.1 & 1.5 & 175 & 273 & 372 & 32 \\
\hline $\mathrm{F} 2$ & 10.6 & 4.3 & 240 & 527 & 816 & 63 \\
\hline \multicolumn{7}{|c|}{ IPC (pasture start) } \\
\hline $\mathrm{F} 1$ & 7.1 & 1.5 & 243 & 252 & 357 & 41 \\
\hline $\mathrm{F} 2$ & 10.6 & 4.3 & 358 & 442 & 701 & 52 \\
\hline \multicolumn{7}{|c|}{ Continuous pastures } \\
\hline $\mathrm{F} 1$ & 7.4 & 1.5 & $84^{\mathrm{c}}$ & 93 & 120 & 30 \\
\hline $\mathrm{F} 2$ & 9.9 & 1.5 & $195^{\mathrm{c}}$ & 111 & 169 & 30 \\
\hline
\end{tabular}

${ }^{a} \mathrm{~N}$ added as urea, $\mathrm{P}$ as super-single phosphate and $\mathrm{K}$ as potassium chloride. Units as $\mathrm{kg}$ of nutrient element ha ${ }^{-1}$

b Micro-nutrients Type BR $=12$. Composed of $9 \% \mathrm{Zn}, 1.8 \% \mathrm{~B}, 0.8 \% \mathrm{Cu}, 2 \% \mathrm{Mn}, 3.5 \% \mathrm{Fe}, 0.1 \% \mathrm{Mo}$

c No $\mathrm{N}$ fertilizer was added to the mixed grass/legume pastures

Only samples from plots/paddocks of continuous pastures and the native Cerrado taken in 2001 and 2013 were analysed for ${ }^{13} \mathrm{C}$ abundance as the cropping sequences consisted of both $\mathrm{C}_{3}$ and $\mathrm{C}_{4}$ crops, which would make meaningful interpretation of ${ }^{13} \mathrm{C}$ abundance data virtually impossible.

Crop and pasture productivity

Crop productivity was estimated by harvesting five areas of $3 \mathrm{~m}^{2}$ in each plot and the yields expressed in $\mathrm{kg} \mathrm{ha}^{-1}$. Animal live weight (LW) was monitored on all pastures throughout the experimental period in order to maintain the correct proportion $(8-10 \%)$ of green material on offer with animal weight. However, as the number and race of cattle per paddock were frequently changed it was not often possible to allocate the live weight gain to a particular treatment or to calculate the LW gain per ha.

\section{Calculations}

Stocks of total $\mathrm{N}$ and $\mathrm{C}$ in the soil under each plot to 30 and $100 \mathrm{~cm}$ depth were calculated using the bulk density data for each plot expressed in $\mathrm{Mg} \mathrm{C}$ or $\mathrm{N} \mathrm{ha}^{-1}$. As tillage operations and treading by grazing cattle compact the soil, the mass of soil to a $100 \mathrm{~cm}$ depth increases compared to the soil under the NV. To correct for this effect the procedure described by Ellert and Bettany (1995) was utilized applying the equation developed by Sisti et al. (2004).

It was assumed that soil compaction due to tillage and treading by cattle was most significant in the surface layers of the profiles so that the $\mathrm{C}$ and $\mathrm{N}$ stocks were calculated by subtracting the total $\mathrm{C}$ and $\mathrm{N}$ content of the extra weight of soil in the deepest $(80-100 \mathrm{~cm})$ layer sampled of each profile. This correction can be expressed mathematically as (Sisti et al. 2004):

$$
\begin{aligned}
\mathrm{C} s= & \sum_{i=1}^{n-1} \mathrm{CT} i \\
& +\left[\mathrm{MT} n-\left(\sum_{i=1}^{n} \mathrm{MT} i-\sum_{i=1}^{n} \mathrm{MS} i\right)\right] \mathrm{CT} n
\end{aligned}
$$

where $\mathrm{Cs}$ is the total $\mathrm{C}$ stock $\left(\mathrm{Mg} \mathrm{C}^{-1}\right)$ in soil to a depth equivalent to the same mass of soil as that in the reference profile (the $\mathrm{NV}$ area), $\sum_{i=1}^{n-1} \mathrm{CT} i$ is the sum of the total carbon content $\left(\mathrm{Mg} \mathrm{ha}^{-1}\right)$ in the layers 1 (surface) to layer ' $\mathrm{n}-1$ ' (penultimate $60-80 \mathrm{~cm}$ ) in the treatment profile, $\sum_{i=1}^{n}$ Msi is the sum of the mass of soil $\left(\mathrm{Mg} \mathrm{ha}^{-1}\right)$ in layer 1 (surface) to ' $\mathrm{n}$ ' $(100 \mathrm{~cm})$ in the reference soil profile, $\sum_{i=1}^{n} \mathrm{MT} i$ is the sum of the mass of soil $\left(\mathrm{Mg} \mathrm{ha}^{-1}\right)$ in layer 1 (surface) to ' $\mathrm{n}$ ' (greatest depth) in the treatment profile, $\mathrm{M}_{\mathrm{Tn}}$ is the mass of soil in the deepest layer $(80-100 \mathrm{~cm})$ in the treatment profile and $\mathrm{C}_{\mathrm{Tn}}$ is concentration of carbon 
$\left(\mathrm{Mg} \mathrm{C} \mathrm{Mg} \mathrm{soil}{ }^{-1}\right)$ in the deepest layer in the treatment profile.

\section{Statistical analyses}

Analyses of variance (ANOVA) and the Student LSD test were used to separate land use treatments and soil fertility effects on soil $\mathrm{C}$ and $\mathrm{N}$ stocks of the most recent soil sampling (year 2013) using the software SISVAR, produced by the Federal University of Lavras (UFL), Lavras, Minas Gerais. In addition, soil C and N stocks for the years 1991, 2001, 2009 and 2013 within the same land use and soil fertility status were compared and separated by using the same tests but in this case considering the time as a single factor. The soil $\mathrm{C}$ and $\mathrm{N}$ stocks under native vegetation corresponded to the year 1991. Soil bulk densities measured in 2013 were compared among treatments within each soil layer also using ANOVA and the Student LSD test. In general, irrespective of existing a comparison, means of the measured variables were presented together with their standard errors.

\section{Results and discussion}

Crop yields

Data for crop yields from individual plots were not available for statistical comparisons to be made between treatments and systems in different years or over the whole 22-year period. Mean soybean yields under the continuous cropping produced between 2.26 and $2.37 \mathrm{Mg}$ grain ha ${ }^{-1}$ under the low (F1) and higher (F2) fertilizer regimes. In the ILC systems these yields were respectively, 3.19 and $3.23 \mathrm{Mg} \mathrm{ha}^{-1}$ for $\mathrm{F} 1$ and F2 in the ICL that started with cropping, but lower at 2.10 and $2.12 \mathrm{Mg} \mathrm{ha}^{-1}$ in the ILC system that started with pasture. The difference here was mainly due to better rainfall in the years that soybean was planted in the ICL system. Soybean yields in commercial crop production in Brazil have increased over the last 22 years and for the Federal District where the experiment was carried out, ranged from $<1.5 \mathrm{Mg} \mathrm{ha}^{-1}$ to approximately $3 \mathrm{Mg} \mathrm{ha}^{-1}$ today, so the yields registered in this study are within the range of local soybean producers. Maize was planted in only five of the 22 years of the study and yields varied widely from 4.2 to $8.6 \mathrm{Mg} \mathrm{ha}^{-1}$. In some years

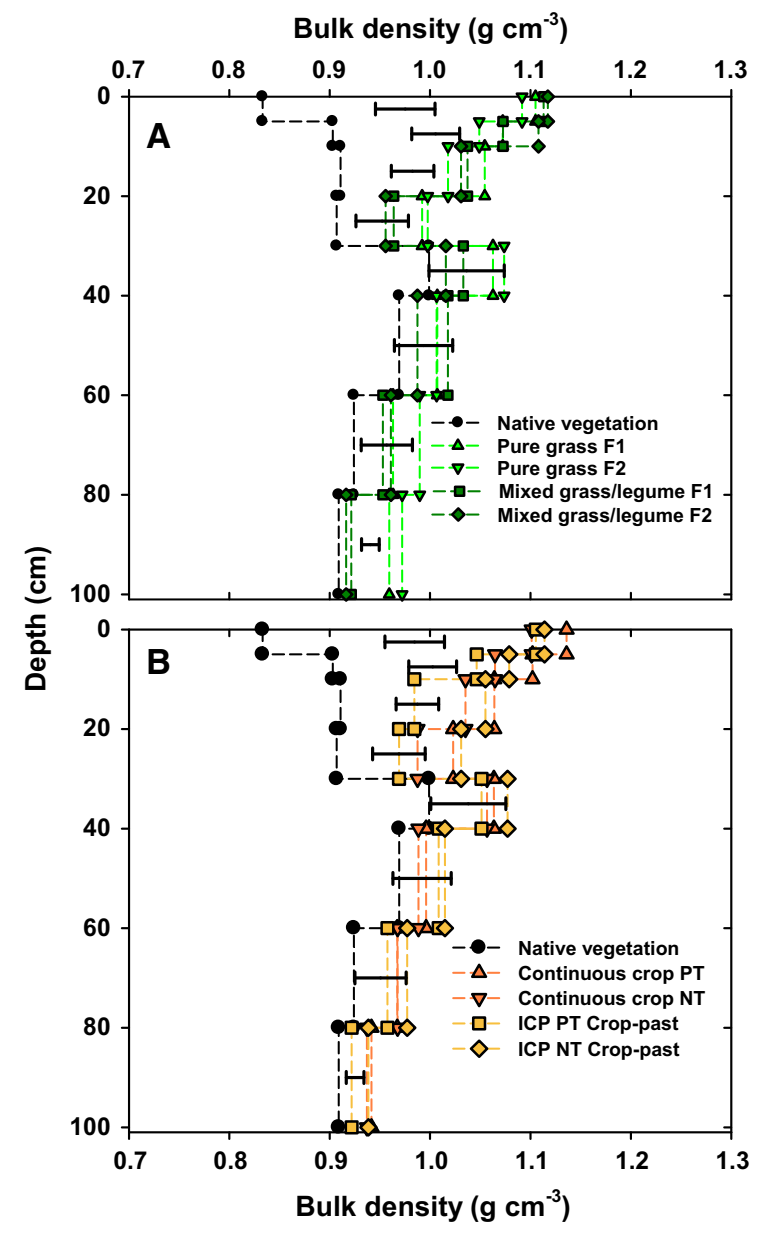

Fig. 1 Soil bulk density under the native Cerrado vegetation compared to the eight principal treatments in the experiment taken from the plots under the higher fertility treatment (F2) to a depth of $100 \mathrm{~cm}$ in eight depth intervals in 2001. Error bars represent the least significant difference at $P<0.05$ (Student LSD test) between means of four replicates

owing to shortage of funding, fertilizer inputs were lower than planned.

Soil bulk density

The results clearly show that that mechanical operations such as ploughing and planting, and the installation and grazing of pastures, compacted the more superficial layers of the soil as witnessed by the increase in soil density (Fig. 1). Where farm machinery had been used (tillage or no-till planters) or pastures had been introduced the soil density was significantly increased $(P<0.05)$ to a depth of $30 \mathrm{~cm}$ 


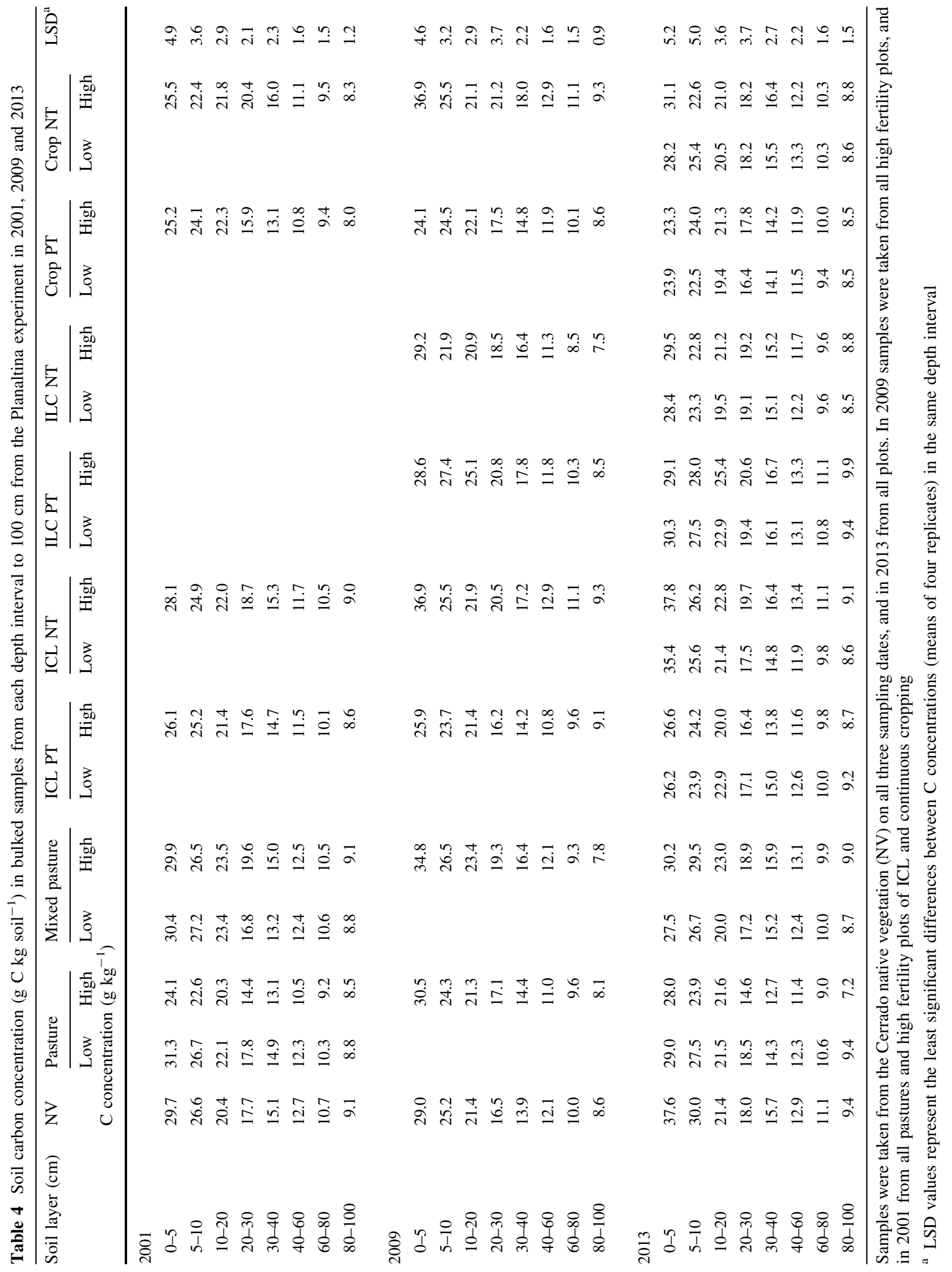




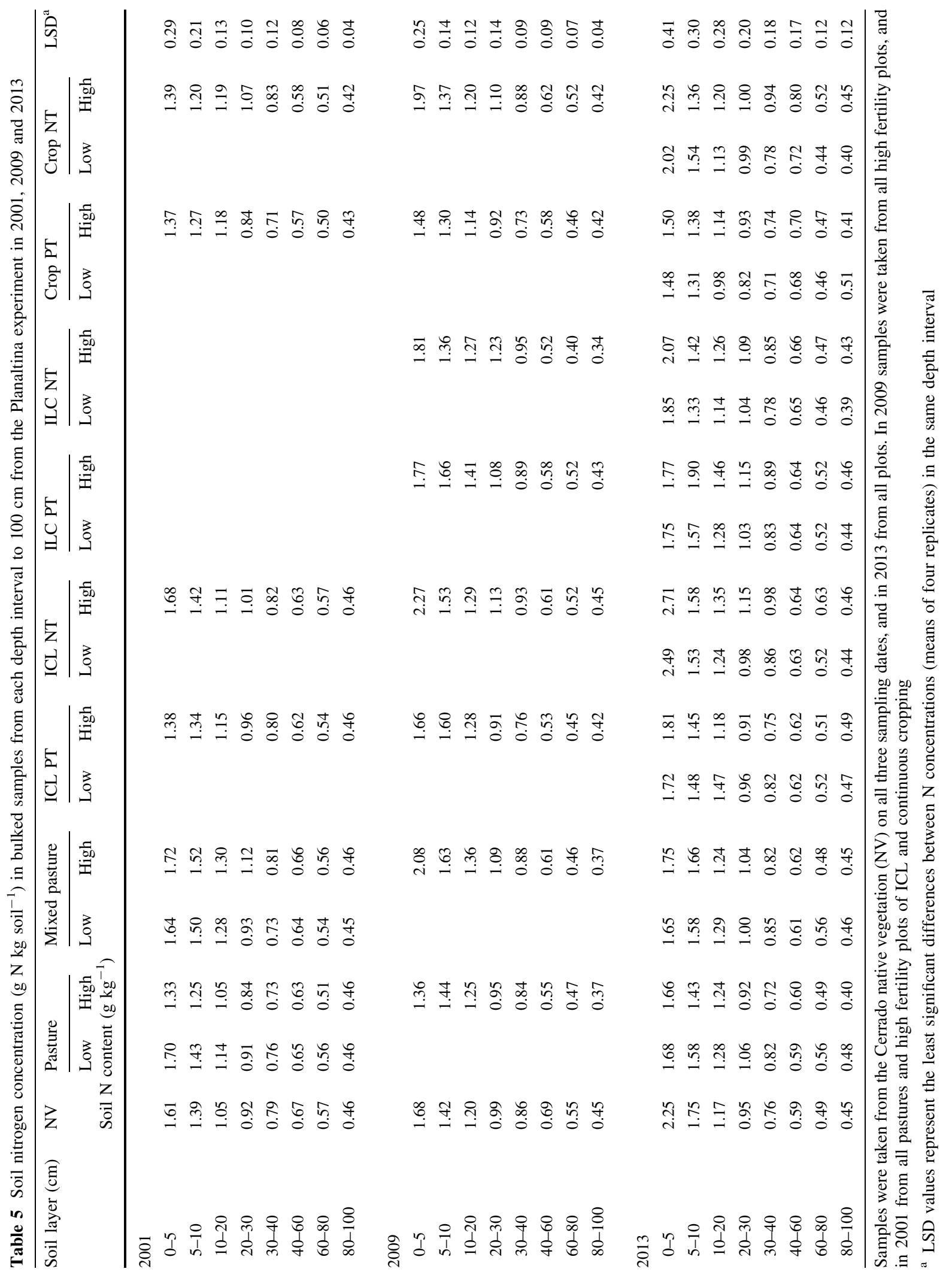


(Fig. 1a, b). Earlier reports from Sisti et al. (2004) and Jantalia et al. (2007) indicated that below $40 \mathrm{~cm}$ depth in Oxisols there are no significant impacts on soil bulk density of traction of agricultural machinery, whether no-till planters, ploughs or harvesters.

\section{Soil $\mathrm{C}$ and $\mathrm{N}$ concentrations}

In all treatments the concentrations of total $\mathrm{C}$ and $\mathrm{N}$ decreased down the profile (Tables 4,5 ), which is a characteristic of most soils under natural vegetation, pastures and no till agriculture (e.g. Bernoux et al. 2002; Groppo et al. 2015), owing to the rapid decline in the mass of crop roots with depth (e.g. Venke Filho et al. 2004; Caires et al. 2008). In an earlier sampling of this same field experiment in 2004 (Marchão et al. 2009) soil $\mathrm{C}$ and $\mathrm{N}$ concentrations were not observed to decrease with depth to $30 \mathrm{~cm}$ but ranged from 17 to $25 \mathrm{~g} \mathrm{C} \mathrm{kg} \mathrm{soil}^{-1}$ and between 1.2 and $1.8 \mathrm{~g} \mathrm{~N} \mathrm{~kg}$ soil $^{-1}$ in the $0-2,2-5,5-10,10-20$ and $20-30 \mathrm{~cm}$ depth intervals. The soil samples were analysed for total $\mathrm{C}$ and $\mathrm{N}$ using near infra-red spectroscopy (NIRS) and as no consistent decreases in soil $\mathrm{C}$ and $\mathrm{N}$ content with depth were observed, we assume that these $\mathrm{C}$ and $\mathrm{N}$ concentrations are incorrect, even though the NIRS results were calibrated with that of 92 samples analysed with an automatic $\mathrm{CN}$ analyser.

As has been observed before in the Cerrado region, the surface $10 \mathrm{~cm}$ of soil under the NV is high in C and this has been attributed to the slow decomposition of recalcitrant root residues of the NV (Roscoe et al. 2001). The soil under many treatments showed a tendency to have higher concentrations of $\mathrm{C}$ and $\mathrm{N}$ than under the NV of the Cerrado especially in the 10-40 cm depth intervals (Tables 4, 5).

$\mathrm{N}$ ratios

The C:N ratio of the soil samples from the area of NV ranged from means of 16.6 in the surface layer to between 21.9 and 23.1 in the depth intervals below $30 \mathrm{~cm}$, which was generally above the ones observed for the respective soil layers, as an average of all treatments, 22 years after land use change (Table 6). It might be expected that under pure grass pastures, where plant litter and roots have high $\mathrm{C}: \mathrm{N}$ ratios, that the surface layers of the soil might have high $\mathrm{C}: \mathrm{N}$ ratios. However root biomass decreases (e.g. Holanda et al. 1998; de Castro and Kauffman 1998; Jobbágy
Table 6 Mean C:N ratio for the soil layers sampled in 2013 from the native vegetation (Cerrado) areas and from the plots of the experiment

\begin{tabular}{lll}
\hline Depth & \multicolumn{2}{l}{ C:N ratio } \\
\cline { 2 - 3 } & Cerrado & Experiment \\
\hline $0-5$ & $16.84 \pm 0.93^{\mathrm{a}}$ & $15.55 \pm 0.31$ \\
$5-10$ & $17.10 \pm 1.08$ & $16.78 \pm 0.19$ \\
$10-20$ & $19.02 \pm 2.39$ & $17.35 \pm 0.24$ \\
$20-30$ & $19.37 \pm 1.81$ & $17.97 \pm 0.21$ \\
$30-40$ & $21.20 \pm 1.93$ & $18.38 \pm 0.25$ \\
$40-60$ & $21.95 \pm 2.27$ & $19.09 \pm 0.41$ \\
$60-80$ & $23.10 \pm 2.61$ & $19.91 \pm 0.32$ \\
$80-100$ & $21.37 \pm 1.44$ & $19.77 \pm 0.32$ \\
Mean & 19.99 & 18.10
\end{tabular}

a Standard error of the means

and Jackson 2000) with depth along with decreased soil microbial activity (Babujia et al. 2010; Oliveira et al. 2004) such that most soil organic matter (SOM) is generally well humified ("heavy fraction") showing $\mathrm{C}: \mathrm{N}$ ratios of less than 12 (Kirkby et al. 2011). Thus it does not seem credible that at deeper levels in the soil profile that (SOM) should show higher $\mathrm{C}: \mathrm{N}$ ratios than at the surface.

Such high C:N ratios have been observed in other regions of the Cerrado. Corbeels et al. (2006) found mean values of 18.1 for the $0-20 \mathrm{~cm}$ depth interval under 45 fields cropped under no-till management in the districts of Rio Verde $\left(17^{\circ} 47^{\prime} \mathrm{S}, 51^{\circ} 55^{\prime} \mathrm{W}\right)$ and Montividiu $\left(17^{\circ} 24^{\prime} \mathrm{S}, 51^{\circ} 14^{\prime} \mathrm{W}\right)$ in the south-eastern part of the Goiás state, some $400 \mathrm{~km}$ south west of Planaltina. In the same region under NV (4 sites) and pastures ( 2 sites) they registered mean $\mathrm{C}: \mathrm{N}$ ratios of 20.6 and 23.2, respectively. The authors did not comment on these high $\mathrm{C}: \mathrm{N}$ values.

However, other studies on Oxisols in the southern region of Brazil the $\mathrm{C}: \mathrm{N}$ ratios down the profile to $100 \mathrm{~cm}$ were found to be close to 12 (e.g. Sisti et al. 2004; Diekow et al. 2005) and similar values were found under an Acrisol (Machado Pinheiro et al. 2010) and an Ultisol (Tarré et al. 2001) in more northerly regions of the Atlantic forest. Kirkby et al. (2011) made a very comprehensive survey on 598 soils (depth intervals not given) from all over the world outside of Australia and 59 Australian soils $(0-15 \mathrm{~cm})$ and arrived at a mean $\mathrm{C}: \mathrm{N}$ value of between 11.5 and 12 . We attribute the much higher $\mathrm{C}: \mathrm{N}$ ratios found under 
this experiment and the neighbouring NV to the presence of charcoal/black carbon as the Cerrado region has a history of regular fires (Coutinho 1990) while the Atlantic forest was cleared with axe or chainsaws and the detritus only burned once (Dean 1995).
Jantalia et al. (2007), working on the Embrapa Cerrados field station at a site only $3 \mathrm{~km}$ from the long-term experiment featured in this present study, found $\mathrm{C}: \mathrm{N}$ ratios in soil sampled at 8 depth intervals to $100 \mathrm{~cm}$ under NV and cropped land between 18 and 23. Initial studies with a stereomicroscope revealed
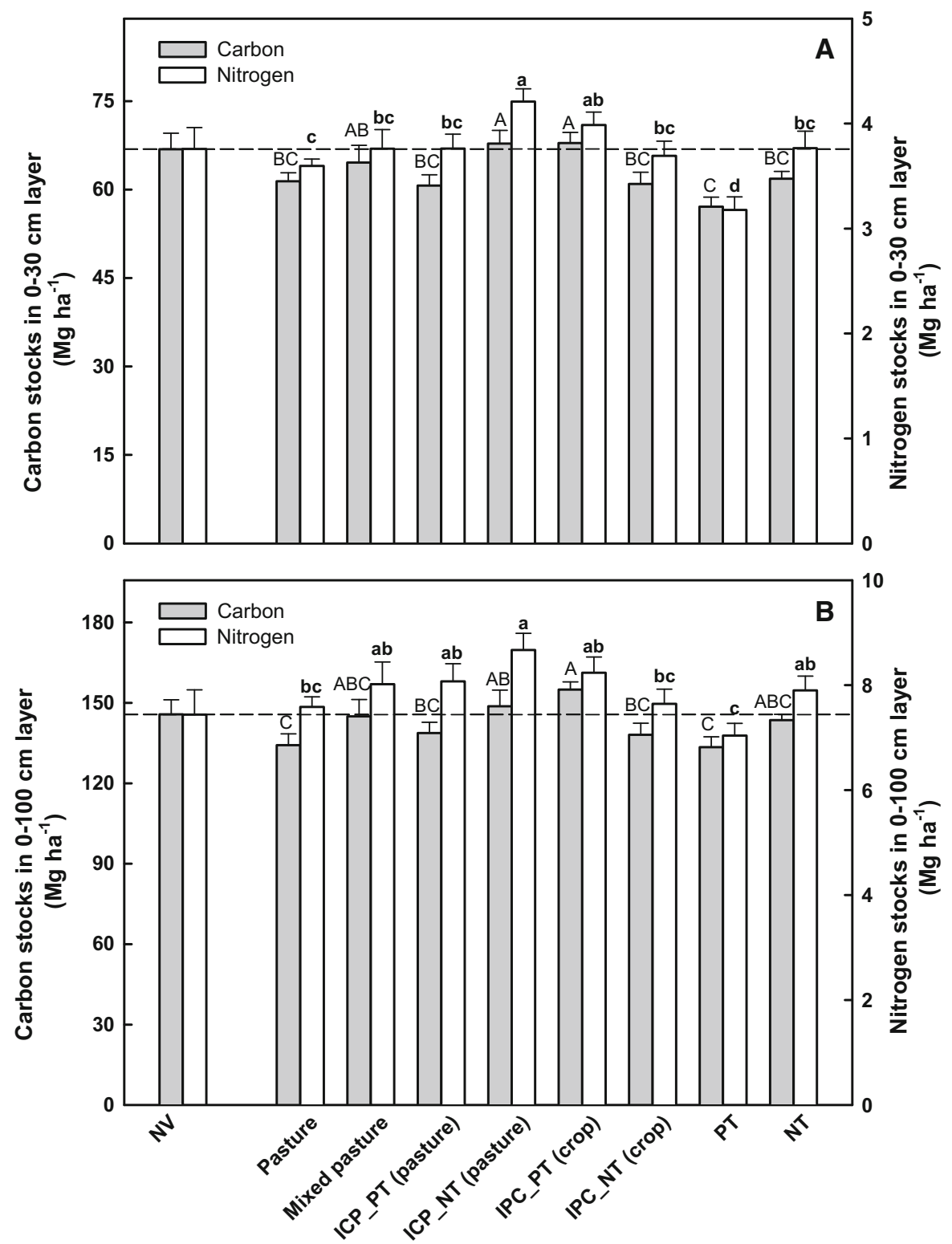

Fig. 2 The stocks of soil $\mathrm{C}$ and $\mathrm{N}$ under each land-use treatment (means of F1 and F2). The soil $\mathrm{C}$ and $\mathrm{N}$ stocks were corrected for an equal mass of soil under the native vegetation to $30 \mathrm{~cm}$ (a) or to $100 \mathrm{~cm}(\mathbf{b})$. Horizontal lines indicate the soil $\mathrm{C}$ and $\mathrm{N}$ stocks under the native vegetation. Bars representing stocks of total $\mathrm{C}$ or $\mathrm{N}$ stocks topped by the same upper-case letters and lower case letters respectively, are not significantly different at $P<0.05$ (Student LSD test) 

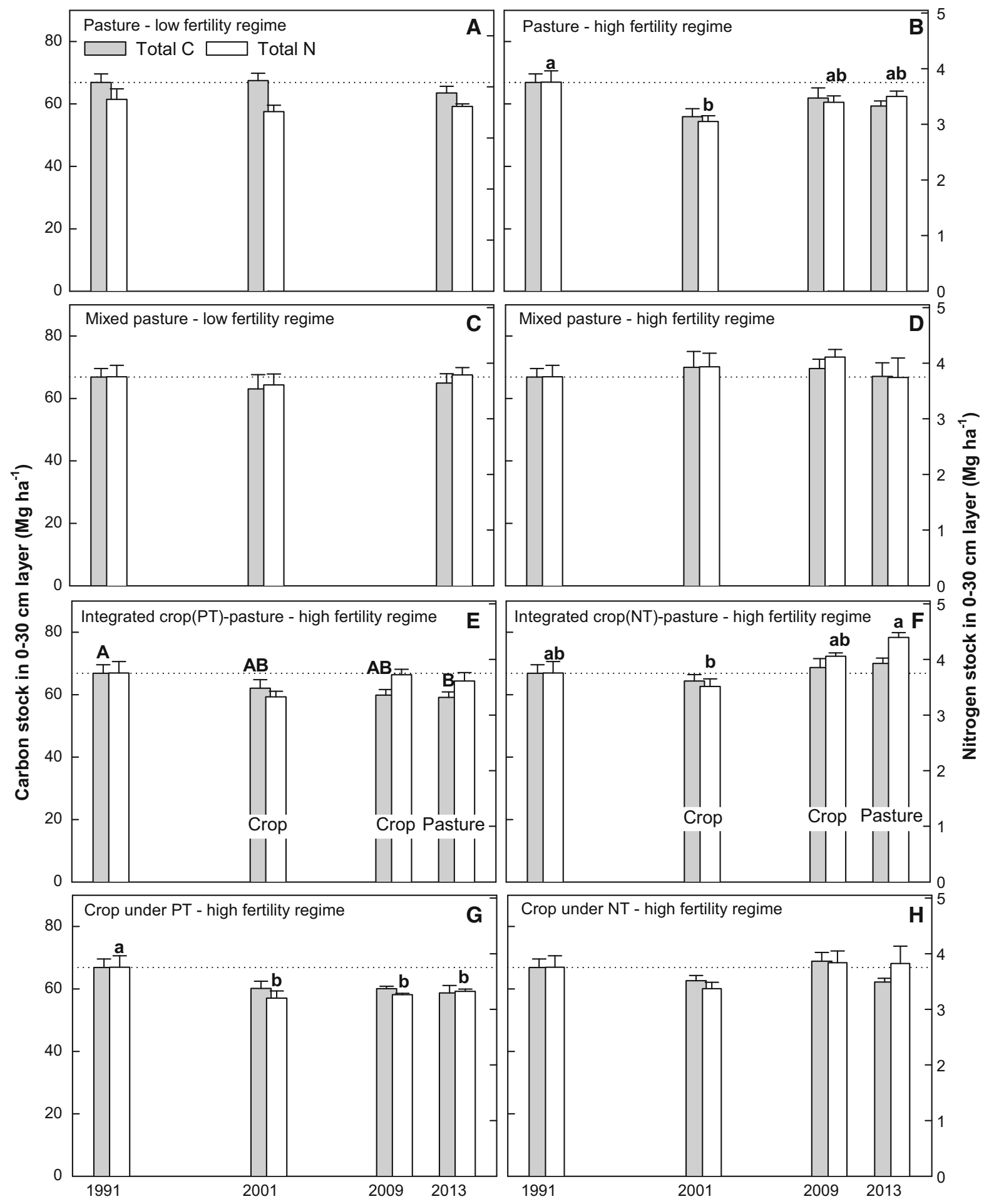
4Fig. 3 Changes in stocks of soil $\mathrm{C}$ and $\mathrm{N}$ to a depth of $30 \mathrm{~cm}$ over a period of 22 years from pure grass and grass/legume pastures at the lower (F1) and higher fertility (F2) regimes, under the ILP treatments (both F2) under no-till (NT) and conventional plough tillage (PT) and the continuous cropping under NT and PT. These stocks were compared with those existing under the undisturbed native vegetation in 2013, which were considered to represent the stocks present in the whole area when the experiment was first established in 1991. Horizontal lines indicate the soil $\mathrm{C}$ and $\mathrm{N}$ stocks under the native vegetation. Bars representing stocks of total $\mathrm{C}$ or $\mathrm{N}$ stocks topped by the same upper-case letters and lower case letters respectively, are not significantly different at $P<0.05$ (Student LSD test)

large numbers of particles of what appeared to be charcoal at all depth intervals. Using a technique based on oxidation with $30 \%$ hydrogen peroxide (Jackson 1958) similar to that of Kurth et al. (2006), Jantalia et al. (2007) concluded that at least $30 \%$ of the soil C was charcoal. We did not have the resources available to analyse charcoal in the soil samples from this experiment. However, as in the experiment plots no fires occurred, any change in soil C stocks would be due to changes in SOC and not charcoal or black carbon.

\section{Soil C and N stocks}

In this experiment, all treatments of pastures, continuous cropping and ICL were cultivated at two different fertility levels: F1 and F2. The fertilizers and lime added to each treatment are given in Table 3. Only in 2013 were soil samples taken from all treatments and it was found that there were no statistical differences $(P>0.05$ - data not shown) between the different fertility levels for the stocks of soil C or N stocks to 30 or to $100 \mathrm{~cm}$ (adjusted for the same mass of soil under the NV to these depths). For this reason, the individual means for F1 and F2 are not displayed. The native Cerrado area was divided into four plots, two at each longitudinal extremity of the experiment. However, as these NV plots were not randomised within the experimental design, no statistical comparison can be made between the $\mathrm{C}$ and $\mathrm{N}$ stocks under these plots and those of the main experiment. However, if it is assumed that these stocks of $\mathrm{C}$ and $\mathrm{N}$ represent those under the area used for the experiment, it appears that the total $\mathrm{C}$ and $\mathrm{N}$ stocks under the grass-only pasture did not increase over the 22 years period. This is in contrast to other reports in the Cerrado (Corazza et al. 1999; Braz et al. 2013) and other regions of Brazil (Moraes et al. 1996; Koutika et al. 1997).
There was a tendency for the presence of legumes in the pasture to increase soil $\mathrm{C}$ and $\mathrm{N}$ stocks compared to the grass-alone pastures, but these differences were not significant at $P<0.05$ to either 30 or $100 \mathrm{~cm}$ depth (Fig. 2). Fisher et al. (1994) reported highly significant increases in $\mathrm{C}$ stocks due to the presence of legumes in a Brachiaria humidicola pasture in the eastern savanna (Llanos Orientales) of Colombia. A positive effect of a forage legume in a pasture of $B$. humidicola on the accumulation of soil $\mathrm{C}$ and $\mathrm{N}$ also was reported by Tarré et al. (2001) in study performed in the coastal Atlantic forest region of the South of Bahia, Brazil.

The most significant differences in soil $\mathrm{N}$ stocks were found in the comparison of NT and PT management of continuous cropping (Fig. 2). To a depth of 30 or $100 \mathrm{~cm}, \mathrm{~N}$ stocks were significantly $(P<0.05)$ higher under NT than under PT. The same tendency was apparent for the $\mathrm{C}$ stocks but the differences were not statistically different at $P<0.05$. There are many reports in Brazil that $\mathrm{C}$ stocks under NT increase after years of conventional PT and, while the first studies investigated stocks to less than $30 \mathrm{~cm}$ (e.g. Bayer and Mielniczuk 1997), subsequent studies have confirmed this to depths well below the plough layer both in the southern region (e.g. Sisti et al. 2004; Diekow et al. 2005) and in the Cerrado (Zinn et al. 2005; Jantalia et al. 2007). These results are consistent with conclusions based on recently published results taken from multiple sites in the Cerrado region (Corbeels et al. 2016) and elsewhere in Brazil (Assad et al. 2013): continuous cropping under NT may increase SOC stocks on land that has been under PT for several years, but the SOC stocks under NT cropping rarely exceed those under the original native vegetation.

The results of the $\mathrm{C}$ and $\mathrm{N}$ stocks under the ICL systems are unexpected. The $\mathrm{C}$ stocks to $30 \mathrm{~cm}$ were highest under two systems: the ICP managed under NT (ICL-NT pasture) sampled in the pasture phase and that managed under PT sampled in the crop phase (ILC-PT crop) (Fig. 2a). These $\mathrm{C}$ stocks were significantly $(P<0.05)$ higher than those under the ICL system managed under PT and sampled in the pasture phase (ICL-PT pasture) or those under the ICL system managed under NT and sampled in the cropping phase (ILC-NT crop). Considering the results from continuous cropping treatments, it is to be expected that management under NT would result in higher stocks of soil $\mathrm{C}$ and $\mathrm{N}$ than ICP managed under conventional 


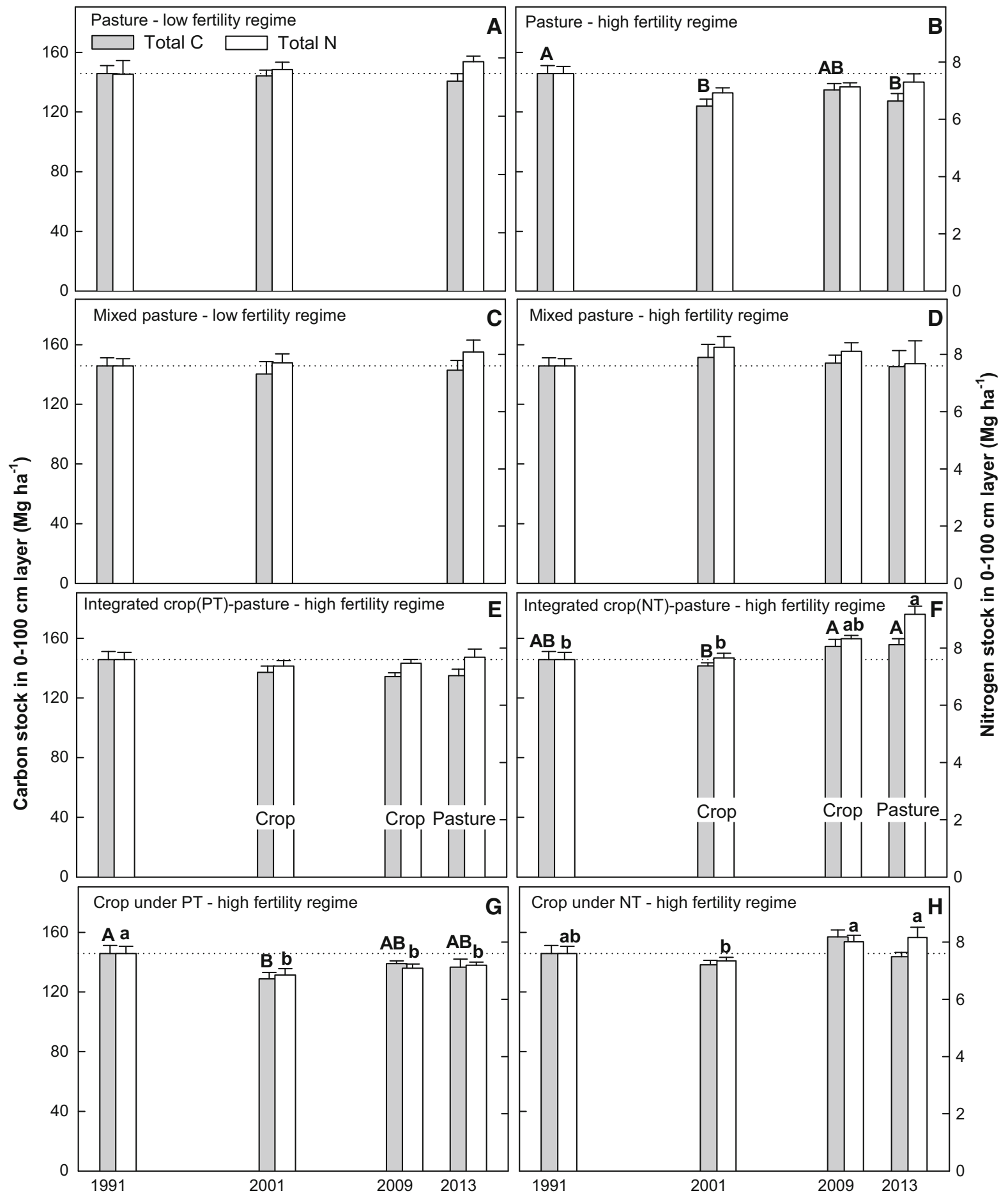

Fig. 4 Changes in stocks of soil $\mathrm{C}$ and $\mathrm{N}$ to a depth of $100 \mathrm{~cm}$ over a period of 22 years from pure grass and grass legume pastures at the lower (F1) and higher fertility (F2) regimes, under the ILP treatments (both F2) under no-till (NT) and conventional plough tillage (PT) and the continuous cropping under NT and PT. These stocks were compared with those existing under the undisturbed native vegetation in 2013, which

were considered to represent the stocks present in the whole area when the experiment was first established in 1991. Horizontal lines indicate the soil $\mathrm{C}$ and $\mathrm{N}$ stocks under the native vegetation. Bars representing stocks of total $\mathrm{C}$ or $\mathrm{N}$ stocks topped by the same upper-case letters and lower case letters respectively, are not significantly different at $P<0.05$ (Student LSD test) 
PT. This trend is not apparent for any of the ICL systems managed under PT or NT and neither were there any consistent differences between the systems sampled during the pasture or cropping phase. In general terms it is apparent that ICL conserved stocks of $\mathrm{C}$ and $\mathrm{N}$ in the soil, compared to conventional PT continuous cropping, but the differences in $\mathrm{C}$ or $\mathrm{N}$ stocks were not always statistically significant at $P<0.05$.

The soil under the plots/paddocks of all higher fertility (F2) treatments (except the ICL starting with cropping) were sampled to $100 \mathrm{~cm}$ depth three times during the experiment, in 2001, 2009 and 2013. All samples were analysed shortly after sampling such that the same instrument or method was not used for all three sets of samples. Hence, as explained in the Materials and methods, all soil samples from 2001 to 2009 to a depth of $30 \mathrm{~cm}$ were reanalysed simultaneously for total $\mathrm{C}$ and $\mathrm{N}$ along with the 2013 samples on the same Costech analyser, coupled or not, to the Finnigan Delta-V mass spectrometer.

From these results were calculated the stocks of total $\mathrm{C}$ and $\mathrm{N}$ for the soils under these $\mathrm{F} 2$ treatments to depths of 0-30 cm (Fig. 3) and 0-100 cm (Fig. 4). Once again, the stocks of $\mathrm{C}$ and $\mathrm{N}$ in 1991, before the installation of the experiment were assumed to be equal to the stocks in the NV areas in 2013. The most striking aspect of the results is that in most treatments the changes in soil $\mathrm{C}$ or $\mathrm{N}$ stocks did not change significantly $(P<0.05)$ with time. In the pastures there were no significant changes in stocks to a depth of $30 \mathrm{~cm}$ of $\mathrm{C}$ or $\mathrm{N}$ except for the high fertility treatment of the grass-alone pasture. Here there was a significant decrease $(P<0.05)$ in $\mathrm{N}$ stock in the period 1991-2005 when measured to $30 \mathrm{~cm}$ and this decrease in SOM was confirmed at the same level of significance for the $\mathrm{C}$ stock to a depth of $100 \mathrm{~cm}$ in 2001 and at the final sampling in 2013.

There was also a significant $(P<0.05)$ fall in the $\mathrm{C}$ stocks to $30 \mathrm{~cm}$ in the ICL system under the high fertility regime managed under PT but this decrease was not significant for the estimate of the stocks of $\mathrm{C}$ or $\mathrm{N}$ to $100 \mathrm{~cm}$. On the other hand, there was a significant increase $(P<0.05)$ in $\mathrm{N}$ stocks to $30 \mathrm{~cm}$ and the $\mathrm{N}$ and $\mathrm{C}$ stocks to $100 \mathrm{~cm}$ depth in the ICL system under the high fertility regime managed under NT. These results are consistent with the hypothesis that ICL systems managed under NT should help to accumulate soil carbon. This was not apparent in the comparison of all the samples taken at the final sampling 2013 (Fig. 2) probably because the effects were attenuated in the low fertility regime.

The time series data also confirm the benefit of the use of NT in conserving soil $\mathrm{C}$ and $\mathrm{N}$ under continuous cropping. Soil N stocks $(0-30 \mathrm{~cm})$ decreased significantly $(P<0.05)$ under PT (high fertility regime) and this was also significant for $\mathrm{N}$ stocks to $100 \mathrm{~cm}$. N stocks $(0-100 \mathrm{~cm})$ under NT also significantly $(P<0.05)$ increased from 2001 to 2013.

Separation of $\mathrm{C}$ derived from native vegetation or $\mathrm{C}_{4}$ grasses

Soil samples taken to $100 \mathrm{~cm}$ depth under the NV and under all four pastures treatments (both F1 and F2) in 2001 and 2013 were analysed, not only for C and $\mathrm{N}$ concentration, but also for ${ }^{13} \mathrm{C}$ natural abundance (Fig. 5). As has been observed before in the Cerrado region, the ${ }^{13} \mathrm{C}$ abundance under the $\mathrm{NV}$ becomes less negative with depth, which indicates that in more recent times there has been an increase in the proportions of trees/shrubs $\left(\mathrm{C}_{3}\right.$ plants $)$ in the natural vegetation (Roscoe et al. 2000; Jantalia et al. 2007; Braz et al. 2013). In 2001 there was a large and significant $(P<0.05)$ difference in ${ }^{13} \mathrm{C}$ abundance of the soil under the $\mathrm{NV}$ and that under the pure grass pastures down to a depth of $40 \mathrm{~cm}$, but no difference between the ${ }^{13} \mathrm{C}$ abundance of the soil under the pastures and the $\mathrm{NV}$ below $80 \mathrm{~cm}$ (Fig. 5a). These differences indicated that there was considerable deposition of $\mathrm{C}_{4}$ grass residues down to a depth of $40 \mathrm{~cm}$ and some $\mathrm{C}_{4}-\mathrm{C}$ deposition as far as $80 \mathrm{~cm}$ depth after 10 years.

However, after a further 12 years of pasture the ${ }^{13} \mathrm{C}$ abundance showed that there was an increase in the deposition of $\mathrm{C}_{4}$ grass residues down the whole of the profile to $100 \mathrm{~cm}$ depth (Fig. 5b). These results indicate that in the Cerrado region, with its long (>5 month) dry season, roots of grasses such as Brachiaria brizantha penetrate to at least $1 \mathrm{~m}$ depth and deposit significant quantities of $\mathrm{C}_{4}$ carbon. Some evidence for this was also found in the study of Braz et al. (2013), but being a study of chronosequences, the evidence was less reliable. Evidence for an input of deep carbon by Brachiaria spp. in a savannah biome (Llanos Orientales of Colombia) was first suggested by the results of Fisher et al. (1994). In contrast, in the South of Bahia which has no marked dry season, Tarré et al. (2001) found no evidence for deposition of $\mathrm{C}_{4}-\mathrm{C}$ 

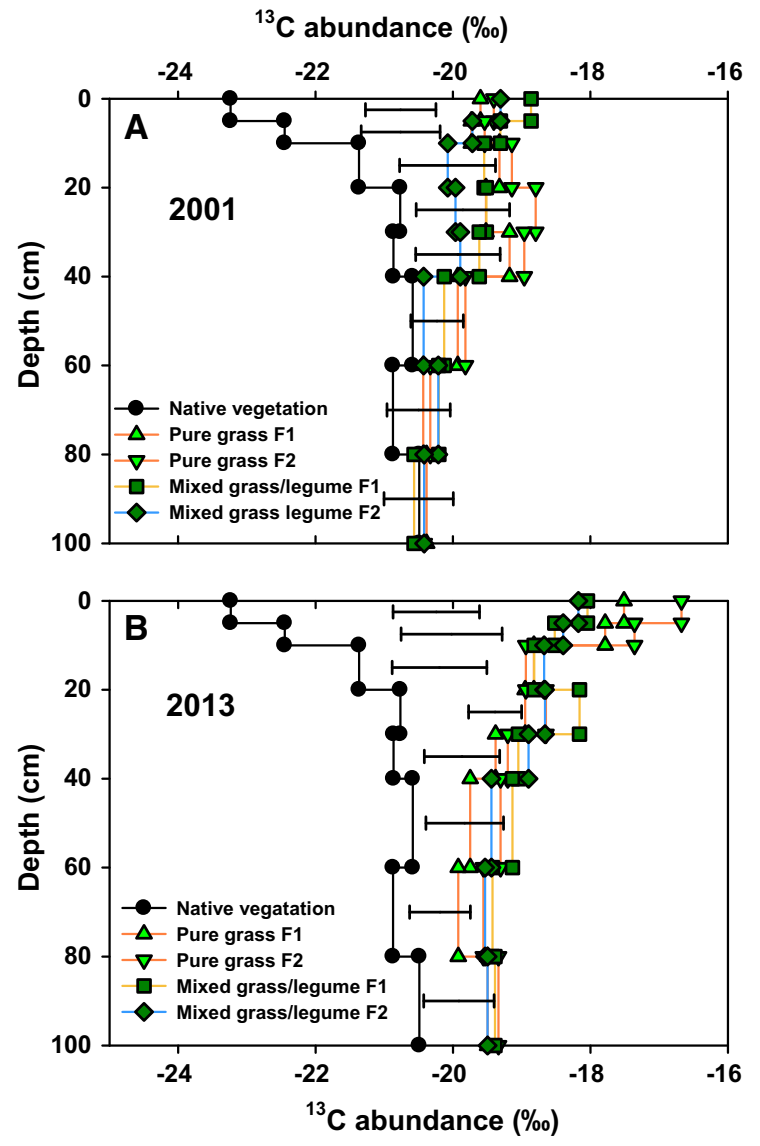

Fig. 5 The ${ }^{13} \mathrm{C}$ natural abundance of soil samples taken to a depth of $100 \mathrm{~cm}$ in eight depth intervals from the pure grass and mixed grass/legume pastures under F1 and F2 fertility regimes in 2001 (a) and 2013 (b). Error bars represent the least significant difference at $P<0.05$ (Student LSD test) between means of four replicates

from $B$. humidicola below $40 \mathrm{~cm}$ depth after 9 years of pasture establishment on an area cleared of Atlantic forest vegetation.

In the case of the mixed grass/legume pastures, any input of legume-derived $\mathrm{C}$ would cause the ${ }^{13} \mathrm{C}$ abundance to become more negative due to inputs of $\mathrm{C}_{3}$ carbon at approximately -27 to $-28 \%$ (Tarré et al. 2001). This effect is clearly visible in the top $10 \mathrm{~cm}$ of the soil after 22 years of pasture (Fig. 5b). However, at depths below $40 \mathrm{~cm}$ in the soil, there was little difference between the ${ }^{13} \mathrm{C}$ abundance of the mixed grass/legume pastures and the pure grass pastures, which suggests that $\mathrm{C}_{4}$ carbon derived from the grass roots was being deposited at depth but that there was no appreciable contribution of legume root- $\mathrm{C}$ deep in the profile.
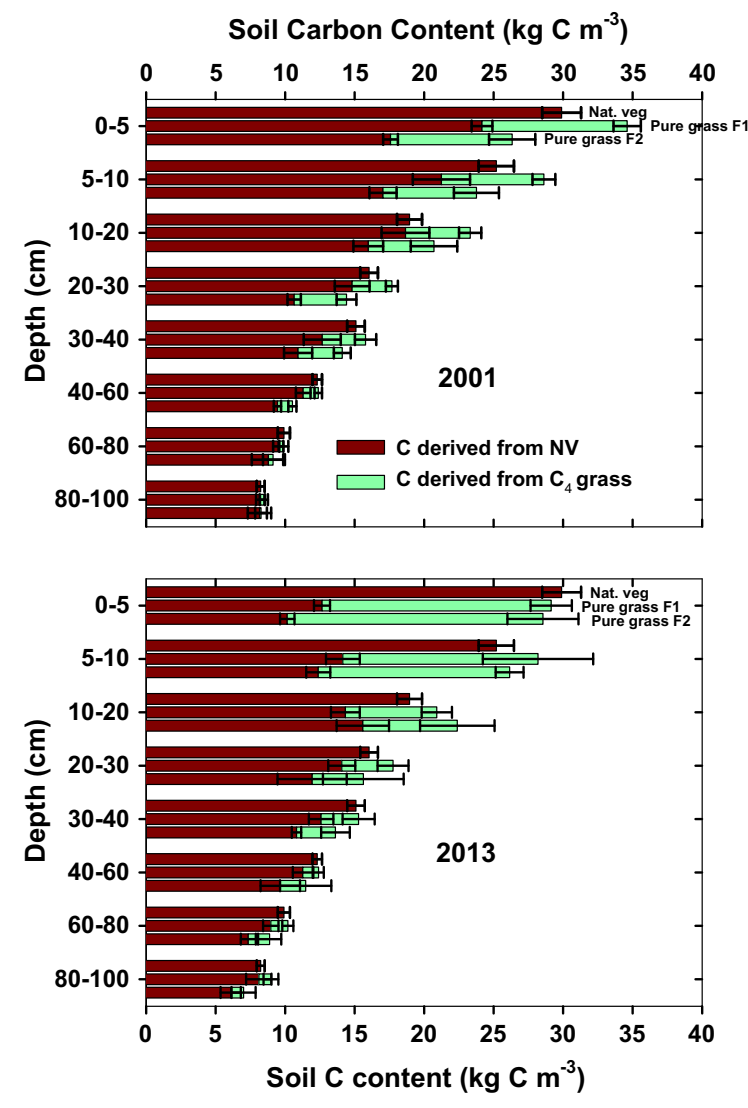

Fig. 6 Carbon $\left(\mathrm{kg} \mathrm{C} \mathrm{m}^{-3}\right)$ derived from the native Cerrado vegetation (NV) and from the $\mathrm{C}_{4}$ grass in the pure grass pasture at the low $(\mathrm{F} 1)$ and high $(\mathrm{F} 2)$ fertility regimes. From top to bottom, the three bars in each group represent the $\mathrm{C}$ under the natural vegetation, pure grass at F1 and pure grass at F2. Error bars represent standard errors of the means of the $\mathrm{C}$ derived from the $\mathrm{NV}$ and the $\mathrm{C}$ derived from the $\mathrm{C}_{4}$ grass

Using the ${ }^{13} \mathrm{C}$ abundance and $\mathrm{C}$ concentration data it was possible to calculate the proportion of $\mathrm{C}$ derived from the $\mathrm{NV}$ and from the $\mathrm{C}_{4}$ grass down the profile (Fig. 6) in the grass-alone treatments. The stocks of the $\mathrm{C}$ derived from the $\mathrm{NV}$ and the Brachiaria corrected to the mass of soil under the NV were calculated for the years 2001 and 2013 for both fertility treatments and compared with the original stock of total $\mathrm{C}$ under the NV.

The data show that from 2001 to 2013 in the 0-20 cm depth intervals, the amount of $\mathrm{C}$ derived from the NV decreased significantly $(P<0.05)$ (Fig. 5). This can only be explained by the fact that in the first 10 years since pasture establishment that the $\mathrm{C}$ derived from the original $\mathrm{NV}$ decomposed more rapidly in the higher fertility treatment. This decrease 
was from 62.5 to $41.0 \mathrm{Mg} \mathrm{C} \mathrm{ha}^{-1}$ in the $0-30 \mathrm{~cm}$ depth interval compared to a decrease to only $51.2 \mathrm{Mg}$ $\mathrm{C} \mathrm{ha}{ }^{-1}$ in the lower fertility treatment, a difference of 10.2 $\mathrm{Mg} \mathrm{C} \mathrm{ha}^{-1}$ (Fig. 7). This difference in the stock of remaining soil $\mathrm{C}$ derived from the $\mathrm{NV}$ to a depth of $100 \mathrm{~cm}$ after 10 years amounted to $20.4 \mathrm{Mg} \mathrm{C}^{-1}$. The amount of $\mathrm{C}$ derived from the $\mathrm{NV}$ to a depth of 30 and to $100 \mathrm{~cm}$ was significantly lower $(P<0.05)$ in the higher fertility treatment (F2) than in F1 in 2001. This trend continued to be apparent for the samples taken in 2013, but the difference was not significantly different at $P<0.05$. The quantities of $C$ derived from the $\mathrm{C}_{4}$ grasses were very similar between the fertility treatments, 22.8 and $22.4 \mathrm{Mg} \mathrm{C}^{-1}$ for F1 and F2,

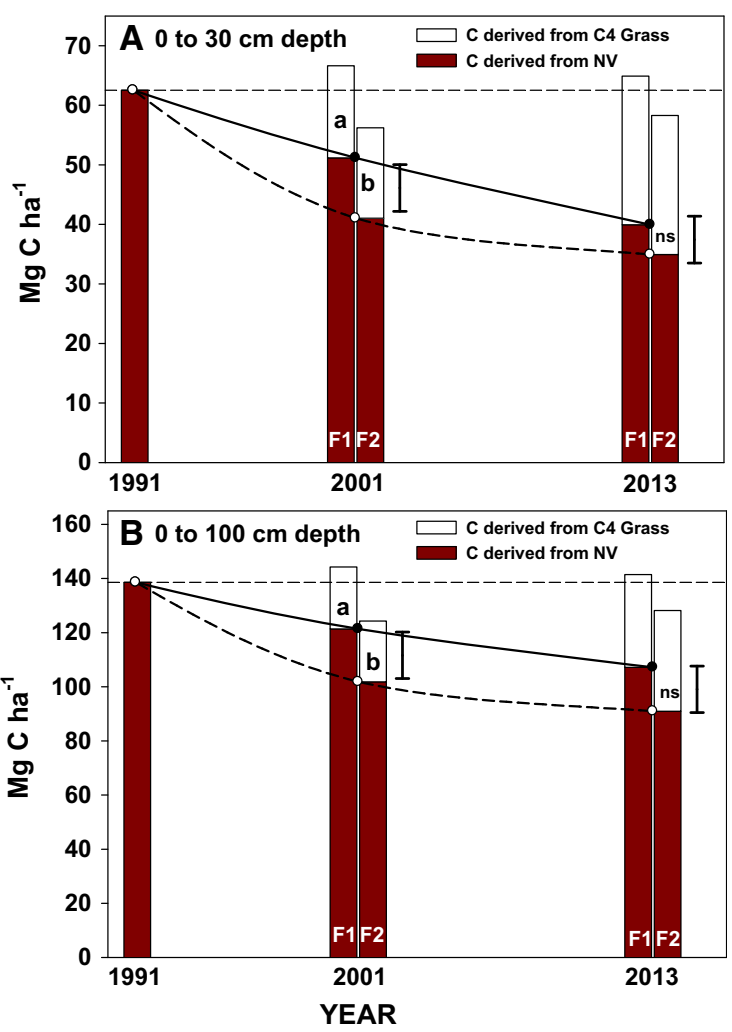

Fig. 7 Stocks of total carbon derived from native vegetation $(\mathrm{NV})$ and the $\mathrm{C}_{4}$ grass corrected for an equal mass of soil under the NV to 30 (a) and to $100 \mathrm{~cm}$ (b) under the pure grass pastures in the low (F1) and high fertility (F2) treatments. The stock of C derived from the NV immediately before the establishment of the experiment in 1991 were assumed to be equal to the stock present under the NV in 2013. The error bars represent the least significant difference at $P<0.05$ (Student LSD test), and different letters and ns (non-significant) all refer to the differences in the stock of $\mathrm{C}$ derived from the NV between the $\mathrm{F} 1$ and $\mathrm{F} 2$ treatments respectively, to a depth of $100 \mathrm{~cm}$ in 2001, and in 2013 these values were, respectively, 34.3 and $37.2 \mathrm{Mg} \mathrm{C}$ $\mathrm{ha}^{-1}$.

These results were unexpected as it was thought that the higher fertility would promote more root growth and hence greater accumulation of soil $\mathrm{C}$. However, the amount of soil $\mathrm{C}$ derived from the $\mathrm{C}_{4}$ grasses was not significantly affected by the amounts of fertilizers added to the pastures, but increased the decomposition rate of the $\mathrm{C}$ derived from the NV. It seems established that soils under higher fertilizer inputs show higher microbial biomass (Geisseler and Scow 2014). This would explain the higher rate of soil $\mathrm{C}$ respiration and hence $\mathrm{C}$ loss, observed in this study. However, in a study at the same field station by de Castro Lopes et al. (2013) higher inputs of P fertilizer which resulted in higher available (Mehlich) P levels were positively correlated with crop yields, microbial biomass- $\mathrm{C}$ and the concentration of soil organic carbon (SOC) to $10 \mathrm{~cm}$ depth. However, whether the original SOM derived from the NV decomposed more rapidly under higher fertilizer inputs could not be determined.

We can find no other reference where a $\mathrm{C}_{4}$ crop was grown for many years on a soil predominantly or partially originating from $\mathrm{C}_{3}$ vegetation and the soil samples subjected to ${ }^{13} \mathrm{C}$ abundance analysis. The results of our study imply that in some circumstances increasing fertiliser additions may lead to higher rates of SOM decomposition and this may not always be compensated for by increased deposition of crop-root derived carbon.

\section{Conclusions}

The results of this long-term study confirm many earlier studies that continuous cropping under conventional plough tillage leads to greater losses of SOC than when managed under no-till. The results also confirm that the presence of a legume in the pastures has a positive effect on soil $\mathrm{C}$ accumulation or conservation. With regard to integrated crop pasture (ICL) systems, the highest carbon stocks were found under these systems, but one treatment where no-till was used throughout to install all crops and pastures, the $\mathrm{C}$ stocks were inexplicably lower than nearly all other treatments. The effect of increasing inputs of lime and $\mathrm{N}, \mathrm{P}$ and $\mathrm{K}$ fertilizers on soil $\mathrm{C}$ stocks under 
continuous $\mathrm{C}_{4}$-grass pastures was contrary to expectations, and showed that soil $\mathrm{C}$ stocks showed a strong tendency to decrease after 10 years of establishment. Using ${ }^{13} \mathrm{C}$ abundance it was found that the amount of soil $\mathrm{C}$ derived from the native vegetation was significantly lower in the higher fertility treatment while the improved fertility had no significant effect on the quantity of $\mathrm{C}$ derived from the $\mathrm{C}_{4}$ grass. In other words, the mineral fertilizers stimulated the decomposition of the $\mathrm{C}$ derived from the SOM present in the NV before the experiment was established.

The important lesson learned from this long-term experiment is that conversion of the Cerrado to cropping, or ICL systems, under NT may not necessarily lead to large gains in soil $\mathrm{C}$. The largest increase in soil $\mathrm{C}$ over 22 years was approximately $16 \mathrm{Mg} \mathrm{C}$ $\mathrm{ha}^{-1}$, and in this tropical climate it is likely that the new equilibrium of the rates of $\mathrm{C}$ deposition and decomposition have been reached and further $\mathrm{C}$ accumulation will not occur (West and Six 2007; Corbeels et al. 2016).

The results suggest that the main benefit of intensifying beef cattle pasture systems in the Cerrado region by use of fertilizers and improved forages, or introducing integrated systems of crop/livestock, does not lie in removing atmospheric $\mathrm{CO}_{2}$ and storing it in soil, although intensification of the systems may reduce emissions of other GHGs per $\mathrm{kg}$ of animal product (Cardoso et al. 2016).

Acknowledgements The authors would like to express their gratitude to all the field workers and technicians at Embrapa Cerrados who have maintained this experiment since 1991. The running of the experiment at Embrapa Cerrados was almost solely funded by different projects of Embrapa. The analyses were funded by Embrapa, the Brazilian National Research Council (CNPq) and the Rio State Research Foundation (FAPERJ). The authors SACSA and JMS, gratefully acknowledge their post-doctoral and $\mathrm{PhD}$ fellowships, respectively, and the authors CPJ, BJRA, SU and RMB grants and fellowships from CNPq and FAPERJ. The diligent work of Renato Moutinho da Rocha in the operation of the total CN analysers and the isotope-ratio mass spectrometers is gratefully acknowledged along with that of the team of the agricultural chemistry laboratory for Kjeldahl and soil fertility analyses.

\section{References}

Arnold SL, Schepers JS (2004) A simple roller-mill grinding procedure for plant and soil samples. Commun Soil Sci Plant Anal 35:537-545
Assad ED, Pinto HS, Martins SC, Groppo JD, Salgado PR, Evangelista B, Vasconcellos E, Sano EE, Pavão E, Luna R, Camargo PB, Martinelli LA (2013) Changes in soil carbon stocks in Brazil due to land use: paired site comparisons and a regional pasture soil survey. Biogeosciences 10:6141-6160

Babujia LC, Hungria M, Franco AA, Brookes PC (2010) Microbial biomass and activity at various soil depths in a Brazilian Oxisol after two decades of no-tillage and conventional tillage. Soil Biol Biochem 42:2174-2181

Bayer C, Mielniczuk J (1997) Nitrogênio total de um solo submetido a diferentes métodos de preparo e sistemas de culturas. Rev Bras Ciênc Solo 21:235-239

Bayer C, Mielniczuk J, Amado TJC, Martin-Neto L, Fernandes SV (2000) Organic matter storage in a sandy clay loam Acrisol affected by tillage and cropping systems in southern Brazil. Soil Till Res 54:101-109

Bayer C, Mielniczuk J, Martin-Neto L, Ernani PR (2002) Stocks and humification degree of organic matter fractions as affected by no-tillage on a subtropical soil. Plant Soil 238:133-140

Bernoux M, Carvalho M da CS, Volkoff B, Cerri CC (2002) Brazil's soil carbon stocks. Soil Sci Soc Am J 66:888-896

Boddey RM, Jantalia CP, Zanatta JA, Conceição PC, Bayer C, Mielniczuk J, Dieckow J, dos Santos HP, Denardin JE, Aita C, Alves BJR, Urquiaga S (2010) Carbon accumulation at depth in Ferralsols under zero-till subtropical agriculture in southern Brazil. Glob Change Biol 16:784-795

Boddey RM, de Carvalho I das NO, Rezende CDP, Cantarutti RB, Pereira JM, Macedo R, Tarré R, Alves BJR, Urquiaga $S$ (2015) The benefit and contribution of legumes and biological $\mathrm{N}_{2}$ fixation to productivity and sustainability of mixed pastures. In: Evangelista AR, Avila CLS, Casagrande DR, Lara MAS, Bernardes TF (eds) Proceedings of the 1st international conference on forages in warm climates. Universidade Federal de Lavras, Lavras, MG 1 to 3 June, pp 103-140. http://www.neforufla.com.br/indexphp/ $\mathrm{pg} / \mathrm{9} /$ anais-confor-2015

Braz SP, Urquiaga S, Alves BJR, Jantalia CP, Guimarães AP, dos Santos CA, dos Santos SC, Machado Pinheiro EF, Boddey RM (2013) Soil carbon stocks under productive and degraded Brachiaria pastures in the Brazilian Cerrados. Soil Sci Soc Am J 77:914-928

Caires EF, Barth G, Garbuio FJ, Churka S (2008) Soil acidity, liming and soybean performance under no-till. Sci Agric 65:532-540

Cardoso A da S, Berndt A, Leytem A, Alves BJR, de Carvalho I das NO, Soares LH de B, Urquiaga S, Boddey RM (2016) Impact of the intensification of beef production in Brazil on greenhouse gas emissions and land use. Agric Syst 143:86-96

Carvalho JLN, Raucci GS, Cerri CEP, Bernoux M, Feigl BJ, Wruck FJ, Cerri CC (2010) Impact of pasture, agriculture and crop-livestock systems on soil C stocks in Brazil. Soil Till Res 110:175-186

Chapuis-Lardy L, Brossard M, Lopes Assad ML, Laurent JY (2002) Carbon and phosphorus stocks of clayey ferralsols in Cerrado native and agroecosystems, Brazil. Agric Ecosyst Environ 92:147-158

Corazza EJ, da Silva JE, Resck DVS, Gomes AC (1999) Comportamento de diferentes sistemas de manejo como 
fonte ou depósito de carbono em relação à vegetação de Cerrado. R Bras Ciênc Solo 23:425-432

Corbeels M, Scopel E, Cardoso A, Bernoux M, Douzet J-M, Siqueira Neto M (2006) Soil carbon storage potential of direct seeding mulch-based cropping systems in the Cerrados of Brazil. Glob Change Biol 12:1773-1787

Corbeels M, Marchão RL, Siqueira Neto M, Ferreira EG, Madari BE, Scopel E, Rodrigues Brito O (2016) Evidence of limited carbon sequestration in soils under no-tillage systems in the Cerrado of Brazil. Nat Sci Rep 6:21450. doi: $10.1038 /$ srep2 1450

Coutinho LM (1990) Fire in the ecology of the Brazilian Cerrado. In: Goldammer JC (ed) Fire in the tropical biotaecosystem processes and global challenges. Springer, Berlin, pp 82-105

da Silva JE, Resck DVS, Corazza EJ, Vivaldi L (2004) Carbon storage in clayey Oxisol cultivated pastures in the "Cerrado" region, Brazil. Agric Ecosyst Environ 103:357-363

de Castro EA, Kauffman JB (1998) Ecosystem structure in the Brazilian Cerrado: a vegetation gradient of aboveground biomass, root mass and consumption by fire. J Trop Ecol 14:263-283

de Castro Lopes AA, de Sousa DMG, Chaer GM, Reis Junior FB dos, Goedert WJ, Mendes I de C (2013) Interpretation of microbial soil indicators as a function of crop yield and organic carbon. Soil Sci Soc Am J 77:461-472

de Moraes JFL, Volkoff B, Cerri CC, Bernoux M (1996) Soil properties under Amazon forest and changes due to pasture installation in Rondônia, Brazil. Geoderma 70:63-81

de Oliveira OC, de Oliveira IP, Ferreira E, Alves BJR, Miranda CHB, Vilela L, Urquiaga S, Boddey RM (2001) Response of degraded pastures in the Brazilian Cerrado to chemical fertilization. Past Tropic 23:14-18

de Oliveira OC, de Oliveira IP, Urquiaga S, Alves BJR, Boddey RM (2004) Chemical and biological indicators of decline/ degradation of Brachiaria pastures in the Brazilian Cerrado. Agric Ecosyst Environ 103:289-300

Dean W (1995) With broadax and firebrand: the destruction of the Brazilian Atlantic Forest. University of California Press, Berkeley

Diekow J, Mielniczuk J, Knicker H, Bayer C, Dick DP, KogelKnabner I (2005) Soil C and N stocks as affected by cropping systems and nitrogen fertilisation in a southern Brazil Acrisol managed under no-tillage for 17 years. Soil Till Res 81:87-95

Eiten G (1972) The cerrado vegetation of Brazil. Bot Rev 38:201-341

Ellert BH, Bettany JR (1995) Calculation of organic matter and nutrients stored in soils under contrasting management regimes. Can J Soil Sci 75:529-538

EMBRAPA (1997) Centro Nacional de Pesquisa de Solos, Manual de métodos de análises de solo. EMBRAPA Centro Nacional de Pesquisa do Solo, Rio de Janeiro

Fisher MJ, Rao IM, Ayarza MA, Lascano CE, Sanz JI, Thomas RJ, Vera RR (1994) Carbon storage by introduced deeprooted grasses in the South American savannas. Nature 371:236-238

Geisseler D, Scow KM (2014) Long-term effects of mineral fertilizers on soil microorganisms - a review. Soil Biol Biochem 75:54-63
Groppo JD, Lins SRM, Camargo PB, Assad ED, Pinto HS, Martins SC, Salgado PR, Evangelista B, Vasconcellos E, Sano EE, Pavão E, Luna R, Martinelli LA (2015) Changes in soil carbon, nitrogen, and phosphorus due to land-use changes in Brazil. Biogeosciences 12:4765-4780

Holanda FSR, Mengel DB, Paula MB, Carvaho JG, Bertoni JC (1998) Influence of crop rotations and tillage systems on phosphorus and potassium stratification and root distribution in the soil profile. Commun Soil Sci Plant Anal 29:2382-2394

Jackson ML (1958) Soil chemical analysis. Prentice-Hall, Englewood Cliffs, p 498

Jantalia CP, Resck DVS, Alves BJR, Urquiaga S, Boddey RM (2007) Effect of tillage intensity on carbon stocks under a soybean based crop rotation in the Brazilian Cerrado. Soil Till Res 85:97-109

Jobbágy EG, Jackson RB (2000) The vertical distribution of soil organic carbon and its relation to climate and vegetation. Ecol Appl 10:423-436

Kirkby CA, Kirkegaard JA, Richardson AE, Wade LJ, Blanchard C, Batten G (2011) Stable soil organic matter: a comparison of C:N:P:S ratios in Australian and other world soils. Geoderma 163:197-208

Koutika L-S, Bartoli F, Andreux F, Cerri CC, Burtin G, Choné T, Philippy R (1997) Organic matter dynamics and aggregation in soils under rain forest and pastures of increasing age in the eastern Amazon Basin. Geoderma $76: 87-112$

Kurth VJ, MacKenzie MD, DeLuca TH (2006) Estimating charcoal content of forest mineral soils. Geoderma 137:135-139

Machado Pinheiro EF, Lima E, Ceddia MB, Urquiaga S, Alves BJR, Boddey RM (2010) Impact of pre-harvest burning versus trash conservation on soil carbon and nitrogen stocks on a sugarcane plantation in the Brazilian Atlantic forest region. Plant Soil 333:71-80

Marchão RL, Becquer T, Brunet D, Balbino LC, Vilela L, Brossard M (2009) Carbon and nitrogen stocks in a Brazilian clayey Oxisol: 13 year effects of integrated croplivestock management systems. Soil Till Res 103:442-450

Mortenson MC, Schuman GE, Ingram LJ (2004) Carbon sequestration in rangelands interseeded with yellow-flowering alfalfa (Medicago sativa ssp. falcata). Environ Manag 33:S475-S481

Neill C, Melillo JM, Steudler PA, Cerri CC, Moraes JFLd, Piccolo MC, Brito M (1997) Soil carbon and nitrogen stocks following forest clearing for pasture in the southwestern Brazilian Amazon. Ecol Appl 7:1216-1225

Nepstad DC, Carvalho CRd, Davidson EA, Jipp PH, Lefebvre PA, Negreiros GH, Silva EDd, Stone TA, Trumbore SE, Vieira S (1994) The role of deep roots in the hydrological and carbon cycles of Amazonian forests and pastures. Nature 372:666-669

Roscoe R, Buurman P, Velthorst EJ, Pereira JAA (2000) Effects of fire on organic matter in a "cerrado senso-stricto" from Southeast Brazil as revealed by changes in ${ }^{13} \mathrm{C}$. Geoderma 95:141-160

Roscoe R, Buurman P, Velthorst EJ, Vasconcellos CA (2001) Soil organic matter dynamics in density and particle size fractions as revealed by the ${ }^{13} \mathrm{C} /{ }^{12} \mathrm{C}$ isotopic ratio in a Cerrado's oxisol. Geoderma 104:185-202 
Salton JC, Mercante FM, Tomazi M, Zanatta JA, Concenço G, Silva WM, Retore M (2014) Integrated crop-livestock system in tropical Brazil: toward a sustainable production system. Agric Ecosyst Environ 190:70-79

Sisti CPJ, Santos HPd, Kochhann RA, Alves BJR, Urquiaga S, Boddey RM (2004) Change in carbon and nitrogen stocks in soil under 13 years of conventional or zero tillage in southern Brazil. Soil Till Res 76:39-58

Smith P, Davies C, Ogle SM, Zanchi G, Bellarby J, Bird DN, Boddey RM, McNamara N, Powlson DS, Cowie A, Van Noordwijk M, Davis S, Richter DD, Kryzanowski L, van Wijk MT, Stuart J, Kirton A, Eggar D, Newton-Cross G, Adhya G, Braimoh A (2012) Towards an integrated global framework to assess the impacts of land use and management change on soil carbon:current capability and future vision. Glob Change Biol 18:2089-2101

Tarré R, Macedo R, Cantarutti RB, de Rezende CP, Pereira JM, Ferreira E, Alves BJR, Urquiaga S, Boddey RM (2001) The effect of the presence of a forage legume on nitrogen and carbon levels in soils under Brachiaria pastures in the
Atlantic forest region of the South of Bahia, Brazil. Plant Soil 234:15-26

Urquiaga S, Cruz KHS, Boddey RM (1992) Contribution of nitrogen fixation to sugar cane: nitrogen-15 and nitrogenbalance estimates. Soil Sci Soc Am J 56:105-114

Venke Filho RR, Feigl BE, Piccolo MC, Fante Junior L, Siqueira Neto M, Cerri CC (2004) Root systems and soil microbial biomass under no-tillage system. Sci Agric 61:529-537

West TO, Six J (2007) Considering the influence of sequestration duration and carbon saturation on estimates of soil carbon capacity. Clim Change 80:25-41

Zinn YL, Lal R, Resck DVS (2005) Changes in soil organic carbon stocks under agriculture in Brazil. Soil Till Res 184:28-40

Zotarelli L, Zatorre NP, Boddey RM, Urquiaga S, Jantalia CP, Franchini JC, Alves BJR (2012) Influence of no-tillage and frequency of a green manure legume in crop rotations for balancing $\mathrm{N}$ outputs and preserving soil organic $\mathrm{C}$ stocks. Field Crop Res 132:185-195 